\title{
Routes Beyond Roots: Alternative ECOlOGICAL Histories In AMITAV GHOSH'S SEA OF POPPIES
}

\author{
MARIA-SABINA DRAGA AlEXANDRU \\ University of Bucharest \\ sabina.draga.alexandru@1ls.unibuc.ro
}

Received: $28-12-2016$

Accepted:02-02-2017

\begin{abstract}
(ㅇ)(1)
\section{Abstract}

This article will read Amitav Ghosh's novel Sea of Poppies as an account of "world histories from below" (Antoinette Burton, 2012) and position the writing of alternative histories of the colonial times within an ecocritical context. While such rewritings have always been a central preoccupation of postcolonial literature, the recent tendency has been to look at history from increasingly local, individualised perspectives. I will examine Ghosh's tracing of routes and connectivities across the Indian Ocean at the time immediately preceding the opium wars, focusing on his reconsideration of human relationships and hierarchies in an ecocritical perspective. This perspective cuts across boundaries established by caste, class, biology, geography and the colonial system, which Ghosh has long been interested in re-evaluating. While on board the Ibis identities become deterritorialised and fluid, they are disconnected from their roots and paths established by rigid culturally conditioned frameworks. Connections are established between the human and other forms of life, forming a continuum across the trade routes of the Indian Ocean, which becomes a fluid space of rebuilding identities. I will use a theoretical framework informed by Bruno Latour's concept of a politics of nature, Donna Haraway's nature-culture negotiations and Rosi Braidotti's eco-conscious ethics.
\end{abstract}

KEYWORDS: routes, roots, ecology, alternative histories, politics of nature, Indian Ocean

\section{RESUMEN Sobre rutas y raíces. Las historias ecológicas alternativas en Mar de amapolas de Amitav Ghosh}

Este artículo leerá la novela de Amitav Ghosh Mar de amapolas como un relato de "historias del mundo de abajo" (Antoinette Burton, 2012) y posicionará la escritura de historias alternativas de la época colonial en un contexto ecocrítico. Aunque tales reescrituras han sido siempre una preocupación central de la literatura poscolonial, la tendencia reciente ha sido mirar la historia desde perspectivas cada vez más locales e individualizadas. Examinaré las rutas y conectividades de Ghosh a través del Océano Índico en el momento inmediatamente anterior a las guerras del opio, centrándome en su reconsideración de las relaciones humanas y las jerarquías en una perspectiva ecocrítica. Esta perspectiva atraviesa los límites establecidos por las castas, las clases, la biología, la geografía y el sistema colonial, que Ghosh está interesado en reevaluar desde hace mucho tiempo. Las identidades se desterritorializan y fluyen a bordo del $\mathrm{Ibis}$, mientras se desconectan de sus raíces y caminos establecidos por rígidos marcos culturalmente condicionados. Se establecen conexiones entre el ser humano y otras formas de vida, formando un continuo a través de las rutas comerciales del Océano Índico, que se convierte en un espacio fluido de reconstrucción de identidades. Utilizaré un marco teórico basado en el concepto de política de la naturaleza de Bruno Latour, las negociaciones naturaleza-cultura de Donna Haraway y la ética eco-consciente de Rosi Braidotti.

PALABRAS ClAVES: rutas, raíces, ecología, historias alternativas, política de la naturaleza, Océano Índico 
Amitav Ghosh's writing explores the "transit lounge of culture", focusing, in the wake of Gloria Anzaldua's Borderlands/ La frontera, which reconceptualises migration as a category of fluidity and change, on "ongoing histories of migrations and transnational cultural flows" (Dixon, 2003: 11). At a time when, according to James Clifford, we can no longer talk of separate, discrete cultures, since all cultures have "histories of border crossings, diasporas and migrations" (Clifford, 1991: 7), Ghosh's fiction has been characterised by an interest in the dynamic of cultures and in cross-border movements, in the always changing nature of identity rather than rigid categories responsible for dividing people. Yet this interest has most visibly increased in his Ibis trilogy (Sea of Poppies, River of Smoke and Flood of Fire), a rather atypical series of historical fiction (spiced with elements of historiographic metafiction, which tells us more about our present than about the historical past), set just before the two mid-nineteenth-century Anglo-Chinese Opium Wars (1839-1842 and 1856-1860). The trilogy is devoted to the complex ways in which the Indian Ocean became a network of connectivities between different geographical spaces and across apparently uncrossable borders, but also between human categories that seem equally unmatchable.

The transformative potential of travel and, generally, of relocation, as well as of the concrete and theoretical dissolution of boundaries that follows from it, has long been a constant preoccupation in Ghosh's work. Robert Dixon notices that “The characters in Ghosh's novels do not occupy discrete cultures, but 'dwell in travel' in cultural spaces that flow across borders - the 'shadow lines' drawn around modern nation states" (Dixon, 2003: 10). While travelling across culture's porous boundaries, leaving behind their roots in favour of routes of transformation, Ghosh's characters escape their subaltern predicament associated with cultures belonging to single places, to inhabit "a discursive space that flows across political and national boundaries, and even across generations in time" (Dixon, 2003: 18). Their perpetual in-betweenness makes them complex, modern characters, with an understanding of human relationships and values that goes far beyond contextual conditionings.

Ghosh opts for an understanding of history that rejects classical ethnography, which "assumes that the culture of the Western observer is a stable and coherent point from which to observe native society" (Dixon, 2003: 18), a view on which colonialism largely relied. By exposing the limitations of such histories written from above, Ghosh critiques “classical anthropology's model of discrete cultures and the associated ideology of nationalism" (20) and proposes a dynamic understanding of culture in its 
historical evolution. In these terms, the "shadow lines" of his 1988 novel's title are perpetually redefined according to the local manifestations and connectivities of an increasingly global world. Through the plural in the title, The Shadow Lines complicates the modernist perspective on borders already signalled by “one of the classic texts of colonialism” (Dixon 19), Joseph Conrad's 1917 novella The Shadow-Line (standing for what, to Conrad, was the invisible line dividing youth from maturity). This points to a necessary effort to remap the colonial and, later, postcolonial world in terms that can encompass the multiplicity of influences and connections triggered by its complex hybrid nature. For Ghosh, the global perspective which should be applied to such definitions dates back a lot further than the contemporary age. In the Ibis trilogy, he focuses on the changes and redefinitions at a time of turmoil in the colonial period, when, just before the opium wars, the British Empire found itself in crisis, as did various traditional South Asian hierarchies. If on land the social rules were still very much in place, the fluid order of the river and, further, of the sea allowed for reshapings of such categories and borders, sometimes in radical ways.

Such a border is the one between nature and culture, which merge and combine into a hybrid that recalls Donna Haraway's concept of "natureculture" in her 2003 book The Companion Species Manifesto. "Natureculture" conceptualises a dynamic, mutually correcting intertwining of the natural with the culturally constructed or the man-made, of the body with the mind, of the rational with the emotional, of the masculine with the feminine etc. It promotes a world in which all that has life of some sort is equal and in which rigid categories such as the ones that have ruled Hindu society for millennia (such as the inviolability of marriage or the incompatibility of castes) are dissolved. Such dissolution grants the world on board the Ibis a flexibility that creates a continuum between humans of different castes, genders and social categories, just as in Haraway's theory a continuum is created between life and the mind, the animal, the human and the man-made (or the machine).

As Hubert Zapf maintains, one of the most important functions of ecocriticism is to project literature as "an ecological principle or an ecological energy within the larger system of cultural discourses" (Zapf, 2006: 55), a form of cultural ecology that has "moved beyond former one-sided, biological-deterministic views of the nature-culture relationship towards the recognition of the difference and relatively independent dynamics of cultural and intellectual phenomena" (Zapf, 2006: 51). The value of imaginative literature as cultural ecology lies in its becoming a means to discuss important political issues more freely and openly than politics can, through the power of example, but also through the capacity of literature to imagine alternative worlds, in which the wrongs of society are 
challenged and sometimes even put right in the possible world constructed in the book.

All the more appropriate is ecocriticism in the postcolonial arena. Dissolving the boundaries between the human and the animal is a theoretical gesture that seems to become increasingly common in recent postcolonial literature, which has reached a new stage where it is taking full advantage of the liberating function of ecocriticism. To Graham Huggan and Helen Tiffin, for example (in their 2010 book Postcolonial Ecocriticism: Literature, Animals, Environment), postcolonial ecocriticism is an opportunity to examine relationships between humans, animals and nature in postcolonial literary texts in order to show that "human liberation will never be fully achieved without challenging the ways human societies have constructed themselves in hierarchical relation to other human and non-human communities, and without imagining new ways in which these ecologically connected groupings can be creatively transformed" (Huggan \& Tiffin, 2010: ii). This involves an important reconsideration of the ways in which we position ourselves with respect to animals and the environment, but also how nature interferes with our actions and decisions, whether we are aware of it or not.

The mission of postcolonial criticism has been to fight off unjustified abuses of colonial power and erase centre-margin dichotomies (some of them absurd by Western standards, such as the boundaries of untouchability between superior castes and lower-caste people or people outside the caste system, who used to be placed on a par, or sometimes lower than animals). With these dichotomies, differences and exclusions that plague societies are also exploded. Taken to its ultimate stage, this involves doing away with the very distinction between the human and the non-human, to the point of aiming at an ecological ethics of "becoming animal", like Rosi Braidotti in Transpositions (2006), and thus claiming equality not just between humans of all kinds, but also between all forms of life, be they human or non-human. A practitioner of such ethics in the arena of postcolonial literature is for example J.M. Coetzee in his 2003 novel Elizabeth Costello. In this novel, the miracle of life is promoted in its apparently most insignificant forms, even when embodied by the minutest beings: the frogs at the end of the novel seem, through their straightforward fight for survival, superior to people. Amitav Ghosh uses nature as a background, but also as a partner in the dialogue through which history is written. He thus rewrites history "from the bottom" rather than from the centre of power, choosing the perspective of disadvantaged individuals, and so performs a similar gesture of celebrating life across artificially set boundaries (be they castes or species).

Bruno Latour famously notices that "we have never been modern" (1991; 1993 for the English translation) and thus views the human in the light of an extended continuum that embraces all 
forms of life in a symbiosis of nature and culture (rather than the separation between them that used to be associated with modernity). I would like to argue that in Sea of Poppies Ghosh retells the official history of colonial India from the perspective of a diverse group of marginalised characters, while various binding, culturally constructed categories, such as caste, marriage and gender, are deconstructed. In doing so, I agree with Antoinette Burton, who sees the concept of world histories from below - the writing of the grand narrative of history by bringing together a diversity of local personal narratives - as characteristic of Ghosh's writing. He thus shifts the emphasis onto the local dimension of history and the ways in which we can follow its traces to this day. I will aim to show that in this process of localised, detail-sensitive history rewriting, the acute presence of the environment and of ecology plays a very important part, as it changes the whole perspective in which inter-human relations are situated and thus seriously challenges the status quo in both Hindu society and the British colonial rule of the time.

In Sea of Poppies (2008), a group of protagonists are brought together by chance. They share stories of traumatic displacement that are in some ways similar, rather atypical as they may be, and thus force them to leave behind their current positions and migrate down the Ganges, and further across the Indian Ocean towards Mauritius. Most of them have contracts as indentured labourers, others are mere adventurers, but all of them share a desire to change location to escape some form of oppression, or are simply in search of a better life. Under the pressure of extreme circumstances, they are united by their understanding of the fact that in extreme situations all prejudice becomes futile and spontaneous, unconditional human bonds are all that matter. In this aspect, they think ahead of their time, like contemporary-minded characters, whom Ghosh uses to dismantle the world of rigid conventionalism in which his plot is set.

Yet, as any historical narrative that privileges the margin over the centre would maintain, we have no way to prove that what people really thought was different at that time from what it is now, as very little of it has ever been documented. Indian New Historicist and subaltern studies scholar Dipesh Chakrabarty signals the deep discrepancy between the subject "history" as taught in universities and educational institutions of various kinds and the local individual "truth" of people's lives, including the point at which they have reached modernity (Chakrabarty, 1992: 19). The novel uses individual cases constructed as extraordinary instances of revolt against the social status quo to challenge, in the spirit of a genuine postcolonial literary ecology, not only the rigid constrictions of society, but also certain assumptions about how history is written. By exploring the individual psychologies of his rule- 
challenging characters, Ghosh also proposes a variety of history that does justice to those who are on the margin, but who actually represent the force of change. From this perspective, he challenges virtually immutable social categories. On board the schooner Ibis, people come together who would never have been able to in terms of the conventions governing society on land. Untouchability no longer matters. Marriage, described as an equally rigid arranged institution in both Hindu society and the British one, relaxes its constrictions when counterposed to the individual force of feelings, entirely neglected by both traditions, but which Ghosh boldly upholds. Gender assumptions are also questioned as male and female characters equally claim their right to living free and happy lives.

Sea of Poppies consists of three parts - Land, River and Sea - which are stages in a ritual journey from a traditional social order, set in stone for centuries (on land) towards liberation from its binding norms (on water). The road to freedom goes down the Ganges, the sacred river of Hindu ritual, which here becomes a path to freedom, and then out at sea. The Ganges, on which the journey starts, to continue at sea on board the Ibis, is associated with a complex plethora of rituals of death, rebirth and purification, in an opening up of Hinduism that significantly borrows its positive focus from the symbolism of nature. What would have been traditionally interpreted as the forbidden gesture of crossing the Black Water, kala pani, is reconstructed here as a collective act of reaching out to freedom, by virtue of which even losing caste is a gain rather than a loss. As they sail down the river on the ship that carries migrants who have been forced by various personal circumstances to uproot themselves and start new lives, the protagonists gradually reinvent themselves. All these people, united by various personal predicaments and dreams of a better future, on a ship that is not exactly what it is officially supposed to be, develop a degree of solidarity amongst themselves that is liberating in itself. As the abusive first mate is murdered at the end of the novel and the mutinous convicts, indentured labourers and migrants take possession of the schooner, they considerably revise social order in this mini-world which they make their own. The Ibis becomes a self-contained utopian universe, driven, despite inevitable residual conflict between some of the crew members, by an ecological ethics through which the social norms that rule on land are suspended and other, much freer alternative rules are established instead.

Thus, Neel Rattan Halder, the zamindar who loses his position on a false charge of forgery by the English opium trader Mr Burnham, is genuinely surprised to find himself, out of necessity, doing things in prison that only an untouchable would normally have done. He learns through experience that touching the untouchable is not at all something to be ashamed of. He is equally 
surprised to discover unconditional human kindness in the tattooist, a man inferior to him in the social hierarchy. Forced to tattoo "forgerer" on Neel's forehead, the man makes the mark a temporary one, out of gratitude to Neel's family having been generous to his own. The hegemonic power of caste in Hindu society is seriously questioned in the novel, as generally in Ghosh's literary ecology.

Such is the freedom conferred by this embracing of the order of nature that Deeti, the widowed village woman, and arguably the novel's main protagonist, saved from her husband's funeral pyre by the untouchable Kalua, carries out an original form of marriage with her saviour, in the middle of nature, totally opposed to the confining order of society. Deeti had never loved her husband, the more so as her daughter Kabutri is the fruit of rape by her brother-in-law on the wedding night, to cover up for her husband's opium-induced impotence. When Kalua unexpectedly saves her, she embraces the life of a migrant alongside her saviour, his untouchable status being no impediment to her. Brought back to life by Kalua's brave gesture of kidnapping her from the destructive fire, where she leaves her vulnerability and her allegiance to society's demands, Deeti marries him in the middle of nature, which becomes a temple of progressive becoming, away from the rigidity of the human world:

Although she had no more of a plan than he did, she said: We'll go away, far away, we'll find a place where no one will know anything about us except that we are married.

Married? he said.

Yes.

Squirming out of his arms, she wrapped herself loosely in her sari and went off towards the river. Where are you going? he shouted after her. You'll see, she called over her shoulder. And when she came back, with her sari draped over her body like a veil of gossamer, it was with an armload of wild-flowers, blooming on the bank. Plucking a few long hairs from her head, she strung the flowers together to make two garlands: one she gave to him, and the other she took herself, lifting it up above his head and slipping it around his neck. Now he too knew what to do and when the exchange of garlands had bound them together, they sat for a while, awed by the enormity of what they had done. Then she crept into his arms again and was swept into the embracing warmth of his body, as wide and sheltering as the dark earth. (Ghosh, 2008: 188-89)

This instance of what we could call true ecological intimacy is crucial in the novel, as it announces a whole series of such transformations that come through the characters' rejection of confining social norms and roles. Deeti herself becomes a spontaneous artist on the occasion of this unplanned wedding that comes from her decision alone, adorning herself and her groom with garlands she makes herself and then consummating a love that is totally authentic, not just free from any arrangements and constrictions. The powerful symbolism of nature as the best host for love and marriage is in tune with a 
necessary ecology of inter-human relations, a plea for authenticity as opposed to convention, for free decision as opposed to tradition-bound family arrangements.

Deeti's disregard of caste is part of a vaster anti-caste statement which the novel is making.. When Kalua negotiates their admission on board the Ibis, early in Part II, this is the official position: “Caste doesn't matter, said the duffadar. All kinds of men are eager to sign up - Brahmins, Ahirs, Chamars, Telis. What matters is that they be young and able-bodied and willing to work" (Ghosh, 2008: 216). While it may be true that the historical conditions which led to the institution of indentured labour changed some of the traditional layout of Hindu society and challenged the inviolability of caste, this statement still sounds strikingly modern and seems to be part of Ghosh's vaster project of questioning Hindu traditions.

Deeti's revolutionary attitude implies a revision of gender assumptions that is sustained by other female characters in the novel. Paulette, subjected to a different form of marginalization, as the orphaned daughter of a French adventurer in India, for whom fighting for her right to a better life is a matter of course, is even more openly unconventional than Deeti. Whether it takes disguising as a lascar or as a native woman in order to reach her goal of being on board the Ibis on the way to Mauritius, nothing can stop Paulette. Second mate Zachary Reid, the octoroon - himself a bordercrosser, the emancipated son of a freed slave whose "skin the colour of old ivory" (Ghosh, 2008: 11) would have make it difficult for him to be socially integrated in his native United States - starts a new life in the rootless, free world of the Ibis, where such details make no difference. The limitations of gender are also questioned as Paulette - singled out by her French-accented English and constructed as a character in a way that is not entirely free from cultural stereotypes about the free-spirited French wants to persuade Zachary to take her on board the Ibis as a lascar in disguise. She is, as we discover, a feminist avant-la-lettre, a worthy follower of a grand-aunt who had travelled the seas alongside male adventurers. As they gradually fall in love with each other, discovering the many things they have in common on account of the many conventions each of them has broken and despite racial and cultural differences, they join the other couples in the novel who cross apparently uncrossable borders to be together.

In the Hindu world, widowhood is an undesirable state perceived as almost interchangeable with death (sati) or leading to seclusion in prayer. For Deeti, on her husband's death, sati is a matter of practical, not religious choice (death being preferable to life as a widow potentially subject to abuse similar to her rape by her brother-in-law on her wedding night). She is lucky to escape it completely 
through her extraordinary abduction by Kalua, which is like a literal rebirth for her. An equally sad fate would have been reserved to Taramony if it hadn't been for the devotion of Baboo Nob Kissin, who becomes not her husband, but her spiritual follower (as she turns into a leader, Ma Taramony). In the British world, marriage is more a means of acquiring social and economic status than of personal fulfilment, as emerges in the discussion on this topic between Paulette and her alleged protectress, Mrs Burnham, who wants to marry her off to her husband's friend, old justice Kendalbushe, despite the girl's desire to marry for love. It is only individual revolt, which Ghosh seems intent to uphold in the name of a contemporary-minded belief in the right of every person to self-determination, that can counteract such established instances of social injustice, and this is precisely what happens in the novel.

Women are traditionally expected to reinvent home in situations of dislocation, and there are many forms of dislocation in the novel. In this multiplicity of situations, women are endowed with almost visionary power, being actually the true revolutionary force. For Ghosh, it is women and the outcastes, the marginalised categories, who possess the power to change history and even to challenge the fiercest categories of social discrimination. As part of this revision, exoticism is turned on its head: from an Indian Ocean pespective, Paulette is seen - not without confirming certain stereotypes related to her being French - as possessing a beauty that is described through the symbolism of nature, a sign of her integration in this space where she has grown to belong through adoption:

At seventeen, Paulette was unusually tall, of a height where she could look over the heads of most of those around her, men and women alike. Her limbs, too, were of such a length that they tended to wave like branches in a wind (years later, this would be her chief complaint about the way she was represented in Deeti's shrine - that her arms looked like the fronds of a coconut palm). (Ghosh, 2008: 132)

Deeti's shrine is the spiritual heart of a home and of stability, which she symbolically carries with her to the end of her journey and, we gather, she will rebuild in her new location on Mauritius. As known, despite some ways in which it is extremely rigid, the Hindu pantheon draws a gradual transition between the divine and the human, so that the distance between the two is not perceived as so immense as in western religions. Some gods, worshipped by local communities only, are almost on a par with the humans who bow to them. Thus, Deeti's inclusion of Paulette, in a future located beyond the end of the novel, welcomes the dream of a hybrid society to which people of different origins belong equally. Nature, where social rules are abolished and the joy of life takes precedence, as well as imagery extracted from nature, stands for the space where the wrongs in society are radically revised and put right. It plays a very important part in Deeti's awakening not only from the dead (literally, from her 
husband's funeral pyre), but also from the social oppression reserved to all women in nineteenthcentury Hindu society. As she is symbolically reborn to a new life, Deeti renames herself by her "good name" Aditi, and her becoming a Chamar is perceived as part of her awakening, as a gain rather than a loss. She goes through a whole ritual of rebirth to a second (better) life, which symbolically takes place just before the end of Part One (Land) and the beginning of the freedom-bringing Part Two (River):

\begin{abstract}
At length, when the journey showed no signs of ending, she plucked up the courage to ask how long the river was and how far the destination. There was no answer, so she called out the name of the boatman of the dead. Then, through the whisper of a deep, hoarse voice it was made known to her that she was alive, in the company of Kalua, on the Ganga - and there was no destination or aim to their journey except to escape. Even then she did not feel herself to be living in the same sense as before: a curious feeling, of joy mixed with resignation, crept into her heart, for it was as if she really had died and been delivered betimes in rebirth, to her next life: she had shed the body of the old Deeti, with the burden of its karma; she had paid the price her stars had demanded of her, and was free now to create a new destiny as she willed, with whom she chose - and she knew that it was with Kalua that this life would be lived, until another death claimed the body that he had torn from the flames. (Ghosh, 2008: 187)
\end{abstract}

The concept of samsara, with birth into a new life following death from the previous one and shedding the burden of the previous karma, is strengthened by the fire imagery. This reminds us of the myth of Shiva Nataraja, who destroys a corrupt world in fire and recreates it through dance. Dance, as a form of art, symbolically creates new life in the myth of Shiva, as love does in the case of Deeti and Kalua. In Deeti's case, rebirth takes place most dramatically. Yet she is not the only character in the novel who experiences some form of reinvention of the self. Love is, in the world of the Ibis, a powerful feeling, acknowledged accordingly, despite the limitations imposed by the world around. From the heartbreaking story of Munia's devouring passion, which she shares with Deeti, to Heeru's wish for a second marriage while her husband, even though he left her, is still alive (a possibility undreamed of in the nineteenth-century Hindu world), the novel problematises marriage from the perspective of women's status at the time, in this particular place in the world. Even though several models of conduct are projected, the female protagonists of the novel generally display a courage of choice that comes from their having nothing to lose, but which in Ghosh's project revises gender relations for the benefit of today's world. When contemplating the possibility of Heeru and Ecka Nack's marriage on the Ibis, despite their being married to other people and despite their caste incompatibility, Deeti, now pregnant with Kalua's child, examines her own doubts about how right her own choices were:

Had they been at home, the match would have been inconceivable - but over there, on the island, what would it matter whether you were from the plains or the hills? For Heeru to set up house with a hillsman would be no different from what she, Deeti, had done herself. Surely all the old ties were immaterial 
now that the sea had washed away their past?

If only it were so!

If the Black Water could really drown the past, then why should she, Deeti, still be hearing voices in the recesses of her head, condemning her for running away with Kalua?

Why should she know that no matter how hard she tried, she would never be able to silence the whispers that told her she would suffer for what she had done - not just today or tomorrow, but for kalpas and yugas, through lifetime after lifetime, into eternity. She could hear those murmurs right now, asking: Do you want Heeru to share the same fate? (Ghosh, 2008: 448)

This subtle questioning of the inner conflict between one's right to personal choice and the pressure of cultural conditioning raises an important issue in the novel: however bravely one may decide to face and eventually even change one's destiny, it takes generations to really silence those inner qualms of conscience that arise from the guilt of having broken the rules. Even though, Deeti does break the rules and takes the necessary steps towards freedom, out of revolt against personal circumstances, her traditional upbringing makes her question her own choices and the similar ones of others (such as Heeru and Ecka Nack). In contrast, Paulette, who comes from an originally western background, is somewhat more liberated, and lives by the model of her grand-aunt's transformation from Jeanne Baret into Jean Bart, a world explorer who proves women's capacity to do jobs that only men used to be thought capable of:

She did the simplest thing, Mr Reid. She tied up her hair like a man and applied to join under the name of Jean Bart. And what is more, she was accepted - by none other than the great Bougainville himself! And it was none too hard, Mr Reid - this I would have you know: it was no more than a matter of wearing a tight band over her chest and lengthening her stride when she walked. Thus she set sail, wearing trousers, just like you, and not one of the sailors or scientists guessed her secret. Can you but imagine, Mr Reid, all those savants, so knowledgeable about the anatomy of animals and plants? - not one of them knew that there was a fillie among them, so completely was she male? (Ghosh, 2008: 268)

Even though this instance of proto-feminism requires dressing like a man, Paulette also takes her grand-aunt's model to reach out to her heart's desire. The river and the ocean are openers of boundaries, of gates towards freedom, so that life ashore, the site of conventionalism, is contrasted to the liberating potential of life at sea:

Once the Ibis had been berthed, Zachary and Serang Ali opened the account books and paid the crew their accumulated addlings. Many of the lascars disappeared immediately into the gullies of Kidderpore, with their copper and silver coins carefully hidden in the folds of their clothing. Some would never see the Ibis again, but some were back in a matter of days, having been robbed or cheated, or having squandered their earnings in toddyshacks and knockingdens - or having discovered, simply, that life ashore was far more attractive when you were at sea than when your feet were a-trip on the slick turf of lubber-land. (Ghosh, 2008: 193) 
To some, life ashore may be more attractive, as it comes with the benefit of predictability. Uncomfortable though change may be, it is, however, through change that progress is made. At the time a space of fruitful commercial activity of which opium trade is one of the (if not the) most important, the Indian Ocean plays the part of a melting pot of all these contrasting tendencies. It is during their passage across the Indian Ocean that assumptions surface and the most important revelations take place.

Opium is an almost divine force that escapes human understanding. To humans it is a source of economic profit, but also an escape to resort to in situations of difficulty. It is used both as a weapon and as a relief from pain, always at hand (Deeti uses it to drug herself before immolation and the tattooist offers it to Neel to take the edge off the pain of having his forehead marked by the tattooing needle). It is an easy source of temporary happiness, but it is also, at this particular point in time, one of the most important bones of contention at the heart of British domination in India, conditioning its relationship with China and its whole position with respect to colonial rule in Asia. The symbolism of poppy fields and of poppy seeds goes hand in hand with that of opium, but not all seeds are equal: some of them, more than others, are of enormous value. On the Ibis, the dying Sarju leaves Deeti a precious pouch of datura and another one of best quality Benares poppy seed, as a sign of her attachment to and appreciation of her. Opium is a force that is almost beyond human power. As the moment of soul-to-soul communication between Sarju and Deeti, before Sarju's death, suggests, it is, ultimately, one of the many languages used or implied in Sea of Poppies. Such communication, which crosses all borders and unites people with little in common, corresponds to a global understanding of the world of a kind that is relevant to the reader in today's perspective, but whose origins Ghosh sees in the $19^{\text {th }}$ century to-and-fro networks of relations across the Indian Ocean.

In many ways, ecological postcolonialism provides answers to historical questions such as the ones that arise in this novel, built around rigid dichotomies that have oppressed people for ages. Even though it corresponds more to the concrete circumstances of life at the time of Ghosh's writing, when globalisation has erased borders and we have been used to questioning cultural givens for some time, it provides a useful lens for interpreting the particularities of the historical period in which the plot of Sea of Poppies is set. To read the past in the light of such an opening toward the fluidity of boundaries and the fragility and temporariness of all definition may seem a creative anachronism at first, but it is actually a gesture of profound recognition of the importance of the reader's perspective on history, which has been informed by such historical events. Thus, when he focuses on the historical 
past, positioning his narrative at times previous to such theories and featuring contemporary-minded characters who prove open to change as their prejudiced upbringing is seriously revised in the face of unusual circumstances, Ghosh does no injustice to historical truth. On the contrary, he makes it relevant and therefore useful to the present moment of its reception.

\section{WORKS CITED}

BRAIDOTTI, ROSI (2006). Transpositions: On Nomadic Ethics, Cambridge \& Malden, MA: Polity.

BURTON, ANTOINETTE (2012). "World Histories from Below", History of the Present, Vol. 2, No1, Spring: 71-77. DOI: 10.5406/historypresent.2.1.0071.

CHAKRABARTY, DIPESH (1992). "Postcoloniality and the Artifice of History: Who Speaks for 'Indian' Pasts?" Representations, No. 37, Special Issue: Imperial Fantasies and Postcolonial Histories, Winter: 1-26. DOI: 10.2307/2928652.

CLIFFORD, JAMES (1991). “The Transit Lounge of Culture”, Times Literary Supplement No 3, May: 7-8.

DIXON, ROBERT (2003). “'Travelling in the West': The Writing of Amitav Ghosh", in: Tabish Khair (ed.) Amitav Ghosh: A Critical Companion, Delhi: Permanent Black, 9-35.

GHOSH, AMITAV (2008). Sea of Poppies, London: John Murray.

HARAWAY, DONNA (2003). The Companion Species Manifesto: Dogs, People, and Significant Otherness (Paradigm), Chicago, IL: Prickly Paradigm Press.

HUGGAN, GRAHAM \& HELEN TIFFIN (2010). Postcolonial Ecocriticism: Literature, Animals, Environment, London \& New York: Routledge.

LATOUR, BRUNO (1993). We Have Never Been Modern, trans. Catherine Porter, Cambridge, MA: Harvard University Press.

ZAPF, HUBERT (2006). "The state of ecocriticism and the function of literature as cultural ecology", in: Catrin Gersdorf and Sylvia Mayer (eds). Nature in Literary and Cultural Studies. Transatlantic Conversations on Ecocriticism, Amsterdam \& New York: Rodopi: 49-69. 
MARIA-SABINA Draga AlEXANDRU is Reader in English at the University of Bucharest. She holds a $\mathrm{PhD}$ in philosophy (University of Bucharest) and a PhD in English (postcolonialism, University of East Anglia). Her main research interests are: global/transnational writing in English, gender studies, postcolonialism and postcommunism. Her latest book is Performance and Performativity in Contemporary Indian Fiction in English (Brill, 2015). 